\title{
HUBUNGAN UMUR, PARITAS DAN FREKUENSI MENYUSUI DENGAN PRODUKSI AIR SUSU IBU
}

\author{
Alice Leiwakabessy ${ }^{1}$, Devi Azriani ${ }^{1}$ \\ ${ }^{1}$ Jurusan Kebidanan, Politeknik Kesehatan Kemenkes Jakarta I, Indonesia
}

Info Artikel Abstrak

Genesis Naskah:

Submissions: $29-10-2020$

Revised: 2-11-2020

Accepted: 16-11-2020

\section{Kata Kunci:}

Frekuensi menyusui, Paritas, Produksi ASI, Umur
Stunting merupakan salah satu masalah gizi yang sedang dihadapi dunia saat ini. Pada tahun 2017 angka stunting di dunia sebesar 22,2\% atau sekitar 150,8 juta anak bawah lima tahun mengalami stunting. Indonesia termasuk ke dalam negara ketiga dengan prevalensi tertinggi di regional Asia Tenggara/South-East Asia Regional (SEAR). Rata-rata prevalensi balita stunting di Indonesia tahun 2005-2017 adalah $36,4 \%$. Penyebab stunting pada balita adalah multifactor seperti kondisi sosial ekonomi, gizi ibu saat hamil, kesakitan pada bayi, dan kurangnya asupan gizi pada bayi. Asupan gizi bayi memegang peranan penting dalam pemberian Air Susu Ibu (ASI). Cakupan pemberian ASI di Indonesia masih belum maksimal. Tahun 2017, cakupan pemberian ASI di Indonesia sebesar 61,33\%. Banyak faktor yang menyebabkan rendahnya pemberian ASI pada bayi antara lain kurangnya produksi ASI. Tujuan penelitian ini adalah mengetahui hubungan umur, paritas dan frekuensi menyusui dengan produksi ASI. Manfaat penelitian adalah sebagai dasar dalam memberikan asuhan untuk meningkatkan produksi ASI. Desain penelitian adalah quasi eksperimen. Intervensi yang digunakan adalah pijat oksitosin dan inisiasi menyusu dini. Populasi penelitian adalah ibu postpartum. Pengambilan sampel menggunakan teknik quota Sampling sebanyak 36 orang. Hasil penelitian didapatkan faktor umur berhubungan terhadap produksi ASI dengan nilai $p=0,022$, paritas dengan nilai $\mathrm{p}=0,053$, dan frekuensi menyusui dengan nilai $\mathrm{P} 0,041$. Kesimpulan penelitian ini adalah terdapat hubungan karakteristik umur, paritas dan frekuensi menyusui terhadap produksi ASI. Saran dari penelitian ini adalah agar petugas kesehatan memperhatikan faktor umur, paritas dan frekuensi menyusui ibu dalam memberikan penyuluhan dan intervensi untuk keberhasilan pemberian ASI pada bayi.

\section{ASSOCIATION OF AGE, PARITY AND FREQUENCY OF BREASTFEEDING ON THE PRODUCTION OF MOTHER'S MILK}

\begin{tabular}{l}
\hline Keywords: \\
Age, Frequency of \\
Breastfeeding, Parity, \\
Milk Production
\end{tabular}

Abstract
Stunting nutrition is one of the problems currently faced by the present world. In
2017 stunting in the world of $22,2 \%$ or approximately 150,8 million children under
five of was stunting. Indonesia including into a state third with prevalence of
highest in southeast asian regional. Prevalence of stunting the average in Indonesia
$2005-2017$ is $36,4 \%$. The causes of stunting in toddlers are multifaktors such as
socioeconomic conditions, maternal nutrition during pregnancy, infant illness, and
lack of nutritional intake in infants. The nutritional intake of babies that plays an
important role is giving breast milk. The rate of breastfeeding in Indonesia is still
not optimal. In 2017, the coverage of breastfeeding in Indonesia was $61.33 \%$. Many
faktors cause low breastfeeding in infants, including a lack of milk production. The
research's purpose was to determine the association of age, parity and frequency of
breastfeeding on milk production. The benefits of research are as a basis for
providing care to increase milk production. The research design was a quasi
experiment. The interventions used were oxytocin massage and early initiation of
breastfeeding.


The population were postpartum mothers in taking the sample using the quota sampling technique with a sample of 36 mothers. The results showed that the age faktor had an effect on breast milk production with $P$ Value 0.022 , parity with $p$ value 0.053, and the frequency of breastfeeding with $p$ value of 0.041. The conclusion of this study is that there is a relationship between the characteristics of age, parity and frequency of breastfeeding on milk production. Suggestion of this study is that service providers pay attention to the faktors of age, parity and frequency of breastfeeding mothers in providing counseling and interventions for the success of breastfeeding in infants

\begin{tabular}{l}
\hline Korespondensi Penulis: \\
Devi Azriani \\
$J l$ Wijayakusuma Raya No. 47 Cilandak Jakarta Selatan, Indonesia \\
deviazriani70@gmail.com \\
\hline
\end{tabular}

Journal of Midwifery Science and Women's Health Volume 1, Nomor 1 Tahun 2020 


\section{PENDAHULUAN}

Stunting atau balita pendek merupakan suatu keadaan yang dialami oleh seorang balita yang memiliki panjang badan/tinggi badan yang kurang jika dibandingkan dengan umur. Balita dikatakan stunting jika memiliki panjang atau tinggi badan lebih dari minus 2 standar deviasi median pertumbuhan anak. (Kemenkes RI, 2018). Stunting ini merupakan masalah gizi yang sedang dihadapi dunia saat ini. Pada tahun 2017 22,2\% atau sekitar 150,8 juta balita di dunia mengalami stunting. Indonesia termasuk ke dalam negara ketiga dengan prevalensi tertinggi di regional Asia Tenggara/South-East Asia Regional (SEAR). Rata-rata prevalensi balita stunting di Indonesia tahun 2005-2017 adalah 36,4\%.(Kemenkes RI, 2018)

Balita stunting merupakan masalah gizi kronik yang disebabkan oleh banyak faktor seperti kondisi sosial ekonomi, gizi ibu saat hamil, kesakitan pada bayi, dan kurangnya asupan gizi pada bayi. Nutrisi yang diperoleh sejak bayi lahir tentunya sangat berpengaruh terhadap pertumbuhannya termasuk risiko terjadinya stunting. Tidak terlaksananya inisiasi menyusu dini (IMD), gagalnya pemberian air susu ibu (ASI) eksklusif, dan proses penyapihan dini dapat menjadi salah satu faktor terjadinya stunting. Sedangkan dari sisi pemberian makanan pendamping ASI (MP ASI) hal yang perlu diperhatikan adalah kuantitas, kualitas, dan keamanan pangan yang diberikan.

Secara nasional, cakupan bayi mendapat ASI eksklusif pada tahun 2017 sebesar $61,33 \%$. ASI mengandung kolostrum yang kaya akan antibodi karena mengandung protein untuk daya tahan tubuh dan pembunuh kuman dalam jumlah tinggi sehingga pemberian ASI eksklusif dapat mengurangi risiko kematian pada bayi. Kolostrum berwarna kekuningan dihasilkan pada hari pertama sampai hari ketiga. Hari keempat sampai hari kesepuluh ASI mengandung immunoglobulin, protein, dan laktosa lebih sedikit dibandingkan kolostrum tetapi lemak dan kalori lebih tinggi dengan warna susu lebih putih. Selain mengandung zat-zat makanan, ASI juga mengandung zat penyerap berupa enzim tersendiri yang tidak akan menganggu enzim di usus. Susu formula tidak mengandung enzim sehingga penyerapan makanan tergantung pada enzim yang terdapat di usus bayi.(Kementerian Kesehatan RI, 2019).
Proses menyusui berhubungan dengan hormon prolactin dan hormone oksitosin. Hormon prolaktin disekresi oleh kelenjar hipofisis anterior yang di stimuli oleh PRH (Prolactin Releasing Hormon) di hipothalamus. Prolaktin bertanggung jawab atas produksi ASI. Rangsangan produksi hormon prolaktin bergantung pada pengosongan ASI dari payudara. Makin banyak ASI yang dikeluarkan atau dikosongkan dari payudara, makin banyak ASI yang dibuat. Proses pengosongan payudara sampai pembuatan ASI disebut reflek prolaktin. Sedangkan rangsangan yang berasal dari isapan bayi akan menghasilkan rangsangan saraf yang dilanjutkan ke dalam kelenjar hipofisis posterior. Akibatnya, hipofisis posterior menghasilkan hormone oksitosin yang menyebabkan sel-sel myoepithelial di sekitar alveoli akan berkontraksi dan mendorong air susu masuk ke pembuluh laktifer sehingga lebih banyak air susu yang mengalir keluar. Keadaan ini disebut reflek oksitosin atau let down reflex. Namun reflek ini dapat dihambat oleh faktor emosi atau psikologis dari ibu (Sarwono Prawirohardjo, 2014)

Menurut Riskesdas 2013, proses mulai menyusui terbanyak terjadi pada 1-6 jam setelah kelahiran $(35,2 \%)$ dan kurang dari 1 jam (inisiasi menyusui dini) sebesar $34,5 \%$. Sedangkan proses mulai menyusui terendah terjadi pada 7-23 jam setelah kelahiran yaitu sebesar 3,7\%. Berdasarkan data dari Kementerian Kesehatan tahun 2016, bayi yang mendapatkan IMD , 1 jam sebanyak 42,7\% dan setelah 1 jam 9,5\%. Sedangkan bayi yang mendapatkan ASI eksklusif sampai 6 bulan sebesar 29,5\% dan yang hanya sampai 5 bulan sebesar 54\%.(Balitbangkes, 2013)

Rendahnya cakupan pemberian ASI berkaitan dengan produksi ASI. Banyak faktor yang berpengaruh terhadap produksi ASI antara lain frekuensi pemberian ASI, Berat bayi saat lahir usia kehamilan saat bayi lahir, usia ibu dan paritas, stres dan penyakit akut, Inisiasi Menyusu Dini (IMD), keberadaan perokok, konsumsi alcohol, perawatan payudara, penggunaan alat kontrasepsi dan status gizi. (Dewi, 2019). Faktor lain yang berpengaruh terhadap pemberian ASI ini adalah faktor sosio-demografi yang meliputi umur, status perkawinan, status pendidikan, pendapatan; faktor bio-fisik yang meliputi pengalaman melahirkan, pengalaman 
menyusui, persepsi kecukupan ASI, lama menyusui; faktor psikososial (Meedya et al., 2010). Tujuan penelitian ini adalah untuk mengetahui hubungan umur, paritas dan frekuensi menyusui yang bermasalah terhadap produksi ASI ibu post partum.

\section{METODE}

Desain penelitian menggunakan eksperimen quasi/eksperimen semu (nonrandomized experiment) bertujuan untuk mengungkapkan hubungan umur, paritas dan frekuensi menyusui terhadap produksi ASI yang dilihat melalui kenaikan berat badan dan jumlah ASI melalui intervensi Inisiasi Menyusu Dini dan pijat oksitosin. Penelitian dilakukan di wilayah tangerang Selatan tahun 2016.

Populasi penelitian ini adalah ibu post partum dengan jumlah sampel 36 orang dibagi dalam kelompok control dan perlakuan. Teknik pengambilan sampel adalah quota sampling. Untuk menilai kenaikan berat badan, dilihat dari selisih berat badan lahir bayi dengan berat badan bayi hari ketiga setelah lahir. Sedangkan untuk jumlah ASI dilihat dari selisih jumlah ASI yang keluar dari hari pertama dan ketiga setelah melahirkan. Cara pengukuran jumlah ASI adalah dengan memompa ASI setiap selesai menyusui bayi dan menjumlahkan ASI yang keluar setiap hari. Pengolahan data meliputi analisis univariat, analisis bivariat menggunakan uji korelasi ( $t$-test) untuk melihat hubungan antara variabel umur, paritas dan frekuensi menyusui dengan produksi ASI berdasarkan kenaikan berat badan bayi dan jumlah ASI yang dikeluarkan dengan teknik pemompaan.

\section{HASIL}

Tabel 1. Distribusi Responden Berdasarkan Umur, Frekuensi menyusui

\begin{tabular}{lcccc}
\hline \multirow{2}{*}{ Variabel } & \multicolumn{2}{c}{$\begin{array}{c}\text { Kelompok } \\
\text { Intervensi }\end{array}$} & \multicolumn{3}{c}{$\begin{array}{c}\text { Kelompok } \\
\text { Kontrol }\end{array}$} \\
\cline { 2 - 5 } & Mean & SD & Mean & SD \\
\hline $\begin{array}{l}\text { Umur } \\
\text { (tahun) }\end{array}$ & 29,1 & 3,6 & 27,9 & 4,6 \\
$\begin{array}{l}\text { Frekuensi } \\
\text { Menyusui }\end{array}$ & 8,9 & 1,8 & 8,4 & 1,3 \\
\hline
\end{tabular}

Distribusi rata-rata umur responden pada kelompok intervensi adalah 29 tahun dan kelompok kontrol 27 tahun. Pada data ini terlihat bahwa rata-rata umur responden baik kelompok control maupun kelompok intervensi berada pada usia reproduksi sehat. Frekuensi menyusui pada kelompok intervensi rata-rata 8,94 kali dalam sehari dan kelompok kontrol 8,44 kali sehari.

Tabel 2. Distribusi Responden Berdasarkan Paritas

\begin{tabular}{|c|c|c|c|c|}
\hline \multirow[t]{2}{*}{ Variabel } & \multicolumn{2}{|c|}{$\begin{array}{l}\text { Kelompok } \\
\text { Intervensi }\end{array}$} & \multicolumn{2}{|c|}{$\begin{array}{c}\text { Kelompok } \\
\text { Kontrol }\end{array}$} \\
\hline & $\mathrm{N}$ & $\%$ & $\mathrm{n}$ & $\%$ \\
\hline Paritas & & & & \\
\hline - Multipara & 13 & 72,2 & 8 & 44,4 \\
\hline - Primipara & 5 & 27,8 & 10 & 55,6 \\
\hline
\end{tabular}

Berdasarkan tabel di atas terlihat paritas kelompok intervensi sebagian besar multipara $(72,2 \%)$ sedangkan kelompok control lebih dari separuhnya primipara $(55,6 \%)$

Tabel 3. Skor Berat Badan Bayi Saat Lahir Dan Hari Ke-3

\begin{tabular}{lcccc}
\hline \multirow{2}{*}{$\begin{array}{c}\text { Berat } \\
\text { Badan } \\
\text { gram })\end{array}$} & \multicolumn{2}{c}{$\begin{array}{c}\text { Kelompok } \\
\text { Intervensi }\end{array}$} & \multicolumn{2}{c}{$\begin{array}{c}\text { Kelompok } \\
\text { control }\end{array}$} \\
\cline { 2 - 5 } & Mean & SD & Mean & SD \\
\hline BB Hari I & 3155,6 & 312,9 & 3083,3 & 200,7 \\
BB Hari & 3377,8 & 520,4 & 3013,9 & 284,8 \\
Ke-3 & & & & \\
$\begin{array}{l}\text { Rata-Rata } \\
\text { Kenaikan }\end{array}$ & 205,6 & 136 & $-69,4$ & 188,8 \\
BB Bayi & & & & \\
\hline
\end{tabular}

Rata-rata kenaikan berat badan pada kelompok intervensi adalah 3 kali rata-rata penurunan berat badan pada kelompok kontrol.

Tabel 4. Skor Jumlah ASI yang Dikeluarkan Saat Pemompaan

\begin{tabular}{lcccc}
\hline \multirow{2}{*}{ Variabel } & \multicolumn{2}{c}{$\begin{array}{c}\text { Kelompok } \\
\text { Intervensi }\end{array}$} & \multicolumn{2}{c}{$\begin{array}{c}\text { Kelompok } \\
\text { Kontrol }\end{array}$} \\
\cline { 2 - 5 } & Mean & SD & Mean & SD \\
\hline $\begin{array}{l}\text { ASI hari I } \\
\text { (cc) }\end{array}$ & 48,3 & 25,9 & 13,3 & 5,1 \\
$\begin{array}{l}\text { ASI Hari } \\
\text { ke-3 }\end{array}$ & 116,2 & 35,5 & 45,3 & 15,2 \\
$\begin{array}{l}\text { Rata-rata } \\
\text { kenaikan }\end{array}$ & 67,8 & 27,3 & 15,6 & 21,4 \\
jumlah \\
ASI
\end{tabular}

Rata-rata jumlah ASI pada kelompok intervensi pada hari 1 adalah 48,33 cc 
sedangkan pada kelompok kontrol adalah 13,33 cc. rata-rata jumlah ASI hari ketiga pada kelompok intervensi adalah 116,17 cc dan kelompok control 45,28 cc. Rata-rata kenaikan jumlah ASI pada kelompok intervensi adalah 67,83 cc sedangkan pada kelompok control $15,56 \mathrm{cc}$.

Tabel 5. Analisis Hubungan Umur, frekuensi menyusui Terhadap Produksi ASI

\begin{tabular}{lcccc}
\hline & \multicolumn{2}{c}{$\begin{array}{c}\text { Kenaikan BB } \\
\text { Bayi }\end{array}$} & \multicolumn{2}{c}{ Jumlah ASI } \\
\cline { 2 - 5 } Variabel & $\begin{array}{c}\mathrm{R} \\
\text { Square }\end{array}$ & $\begin{array}{c}\mathrm{P} \\
\text { value }\end{array}$ & $\begin{array}{c}\mathrm{R} \\
\text { Square }\end{array}$ & $\begin{array}{c}\mathrm{P} \\
\text { value }\end{array}$ \\
\cline { 2 - 5 } Umur & 0,381 & 0,022 & 0,216 & 0,205 \\
$\begin{array}{l}\text { Frekuensi } \\
\text { Menyusui }\end{array}$ & 0,123 & 0,473 & 0,343 & 0,041 \\
\hline
\end{tabular}

Berdasarkan uji korelasi, dari 2 (dua) variable independen didapatkan hasil bahwa umur berhubungan terhadap kenaikan berat badan bayi dengan nilai $\mathrm{P}=0,022$, sedangkan frekuensi menyusui tidak ada hubungan bermakna terhadap kenaikan berat badan bayi dengan nilai $\mathrm{P}>0,05$. Berdasarkan uji korelasi, dari 2 (dua) variable independen didapatkan hasil bahwa umur tidak bermakna terhadap kenaikan jumlah ASI dengan nilai $p>0,05$, sedangkan frekuensi menyusui memiliki hubungan bermakna dengan jumlah ASI dengan nilai $\mathrm{P}$ $=0,041$.

Tabel 6. Analisis Hubungan Paritas dengan Produksi ASI

\begin{tabular}{lcccc}
\hline Variabel & Mean & SD & N & $\begin{array}{c}\text { P } \\
\text { value }\end{array}$ \\
\hline $\begin{array}{l}\text { Kenaikan BB bayi } \\
\text { Paritas: }\end{array}$ & & & & \\
- Multipara & 3283,3 & 291,7 & 21 & 0,053 \\
- Primipara & 3073,3 & 332,6 & 15 & \\
Jumlah ASI & & & & \\
Paritas: & 86,48 & 40,1 & 21 & 0,371 \\
- Multipara & 86,48 & 40,1 & 21 & 0,371 \\
- Primipara & 72,67 & 51,3 & 15 & \\
\hline
\end{tabular}

Berdasarkan uji statistik didapatkan hasil bahwa paritas berhubungan dengan kenaikan produksi ASI dilihat dari variabel kenaikan berat badan bayi dengan nilai $\mathrm{P}=0,053$. Namun paritas tidak memiliki hubungan bermakna dengan produksi ASI jika dilihat dari variable jumlah ASI dengan nilai $p>$ 0,05 .

\section{PEMBAHASAN}

\section{Umur Ibu dengan Produksi ASI}

Penelitian Pranajaya (2013) menjelaskan bahwa umur seorang individu dihitung mulai dari saat kelahiran sampai dengan ulang tahun terakhir. (Pranajaya dkk, 2013). Rentang umur reproduksi yang sehat adalah pada usia 20-35 tahun. Periode tersebut merupakan periode yang paling baik untuk hamil, melahirkan dan menyusui. Dalam kurun waktu reproduksi sehat produksi ASI akan cukup karena fungsi alat reproduksi masih dapat bekerja secara optimal. Ibu yang berusia 35 tahun dianggap berbahaya karena baik alat reproduksinya maupun organ tubuh lainnya sudah mengalami penurunan sehingga resiko terjadinya komplikasi baik dalam kehamilan, persalinan dan menyusui sangat tinggi (Sarwono Prawirohardjo, 2014).

Dari hasil penelitian terlihat bahwasanya rata-rata umur responden baik kelompok control maupun perlakuan berada pada periode reproduksi sehat. Pada hasil analisis statistic terlihat bahwasanya umur ibu berhubungan dengan kenaikan berat badan bayi. Hal ini menunjukkan bahwa produksi ASI yang dihasilkan dari ibu tersebut memenuhi kebutuhan bayi yang terlihat dari kenaikan berat badan bayi. Meskipun jika dilihat dari jumlah ASI, umur ibu tidak berhubungan dengan produksi ASI. Hal ini bisa disebabkan oleh faktor lain seperti kemampuan memompa ASI dan waktu pemompaan yang tidak tepat.

Hasil penelitian ini sejalan dengan penelitian Lorenzo, dkk (2018) yang menjelaskan bahwa umur ibu berhubungan dengan perilaku menyusui, dimana ibu yang lebih tua cenderung malas menyusui dibandingkan dengan ibu yang lebih muda. Meskipun hal ini tidak langsung berkaitan dengan fungsi reproduksi, namun hasil penelitian ini tetap berdampak terhadap 
produksi ASI.(Colombo et al., 2018). Penelitian lain yang mendukung hasil penelitian ini adalah penelitian yang dilakukan oleh Kitano, dkk (2016) yang menjelaskan bahwa umur ibu yang > 35 tahun dan paritas primipara merupakan faktor negative keberhasilan pemberian ASI khususnya inisiasi menyusu dini (Kitano et al., 2016). Hal ini akan berdampak kepada produksi ASI, dimana inisiasi menyusu dini memegang peranan penting terhadap produksi ASI. Isapan bayi pada saat IMD akan mempengaruhi produksi hormone prolactin dan hormone oksitosin dimana kedua hormone ini memegang peranan penting produksi ASI.

\section{Paritas ibu dengan produksi ASI}

BKKBN menjelaskan bahwa paritas adalah banyaknya kelahiran hidup yang dipunyai oleh seorang wanita. Paritas dapat dibedakan menjadi primipara, multipara dan grandemultipara. Paritas adalah jumlah kehamilan yang menghasilkan janin yang mampu hidup diluar rahim (28 minggu) (Sarwono Prawirohardjo, 2014).

Hasil penelitian menunjukkan bahwa paritas ibu berhubungan dengan produksi ASI yang dilihat dari variable kenaikan berat badan bayi, meskipun paritas tidak berhubungan dengan produksi ASI dari variable jumlah ASI. Hasil penelitian ini sejalan dengan penelitian Frieska, dkk (2018) yang menjelaskan bahwa paritas berhubungan dengan awal laktasi. Awal laktasi ini akan menentukan keberhasilan pemberian ASI berikutnya (Frieska. P, Windhu. P, 2018). Paritas primipara adalah faktor negative keberhasilan menyusui terkait dengan IMD. Hal ini berarti bahwa ibu primipara cenderung gagal dalam pelaksanaan IMD.

ASI akan diproduksi lebih banyak pada ibu yang melahirkan lebih dari satu kali. Hal ini disebabkan karena mereka lebih memiliki pengetahuan dan pengalaman yang lebih banyak tentang proses menyusui sehingga manajemen laktasi akan dijalankan dengan baik. Menurut Soejtiningsih (1997) kesiapan psikologis antara primipara dan multipara sangat berbeda. Seorang primipara lebih mudah merasa cemas dan labil kondisi psikologisnya hal ini akan mempengaruhi pengeluaran hormon yang berperan dalam produksi ASI (Pranajaya dkk, 2013).

\section{Frekuensi menyusui dan produksi ASI}

Isapan bayi berdampak terhadap produksi ASI, karena isapan bayi akan mempengaruhi pengeluaran hormone prolactin yang berfungsi untuk memproduksi ASI. Selain itu, isapan bayi juga akan meransang pengeluaran hormone ositosin. Frekuensi menyusu bagi masing-masing ibu akan berbeda yang dipengaruhi oleh beberapa faktor antara lain kondisi kesehatan bayi. Menurut hasil penelitian Hopkinson pada studi 32 ibu dengan bayi prematur disimpulkan bahwa produksi ASI akan optimal dengan pemompaan ASI lebih dari 5 kali per hari selama bulan pertama setelah melahirkan. Pemompaan dilakukan karena bayi prematur belum dapat menyusu. Studi lain yang dilakukan pada ibu dengan bayi cukup bulan menunjukkan bahwa frekuensi penyusuan $10-13$ kali perhari selama 2 minggu pertama setelah melahirkan berhubungan dengan produksi ASI yang cukup (Pranajaya dkk, 2013).

Hasil penelitian ini didapatkan rata-rata frekuensi menyusui ibu adalah sekitar 5-12 kali perhari. Hasil analisis statistic menjelaskan bahwa terdapat hubungan antara frekuensi menyusui dengan jumlah ASI ibu, namun tidak didapatkan hubungan antara frekuensi menyusui dengan kenaikan berat badan bayi. Hal ini menjelaskan bahwa meskipun frekuensi menyusui ibu cukup sering, namun masih belum begitu berdampak terhadap produksi ASI. Hasil penelitian ini sejalan dengan penelitian yang dilakukan oleh Rahmawati, dkk (2017) yang menjelaskan bahwa terdapat hubungan antara frekuensi menyusui dengan produksi ASI. Rata-rata frekuensi menyusui dalam sehari adalah 10-12 kali. Frekuensi menyusui ini merupakan proses pengosongan payudara yang akan memberikan signal kepada hipotalamus untuk mensekresi hormone prolactin. Selain itu, frekuensi 
menyusui ini berhubungan juga dengan isapan bayi. Isapan ini akan meransang hormone hipofise posterior untuk mengahsilkan hormone oksitosin (Rahmawati \& Prayogi, 2017).

Penelitian Trio, dkk (2015) menjelaskan bahwa frekuensi menyusui dengan kenaikan berat badan bayi memiliki hubungan yang signifikan. Hal ini disebabkan karena hisapan bayi dapat merangsang kelenjar di sekitar areola mammae untuk mensekresikan hormone oksitosin yang berfungsi untuk mendorong ASI keluar (Trio Linda F.E.R, 2015).

Hasil penelitian ini sejalan dengan penelitian Pranajaya, dkk (2013) yang menjelaskan bahwa frekuensi menyusui tidak akan menghasilkan ASI yang cukup, namun banyak hal yang berpengaruh terhadap produksi ASI antara lain kecemasan ibu dan asupan gizi ibu. Faktor lain adalah kekuatan isapan dari bayi itu sendiri. (Pranajaya dkk, 2013).

\section{KESIMPULAN}

Kesimpulan penelitian ini adalah umur dan paritas ibu berhubungan dengan produksi ASI dilihat dari kenaikan berat badan bayi, sedangkan frekuensi menyusui tidak bermakna terhadap produksi ASI dilihat dari jumlah ASI yang dikeluarkan ibu saat pemompaan.

Berdasarkan kesimpulan ini, disarankan agar para tenaga kesehatan dalam memberikan konseling menyusui yang terkait dengan produksi ASI untuk memperhatikan faktor umur, paritas dan frekuensi menyusui.

\section{DAFTAR PUSTAKA}

Balitbangkes. (2013). Riset Kesehatan Dasar 2013.

Colombo, L., Crippa, B. L., Consonni, D., Bettinelli, M. E., Agosti, V., Mangino, G., Bezze, E. N., Mauri, P. A., Zanotta, L., Roggero, P., Plevani, L., Bertoli, D., Giannì, M. L., \& Mosca, F. (2018). Breastfeeding determinants in healthy term newborns. Nutrients, 10(1), 5-8. https://doi.org/10.3390/nu10010048

Dewi, A. D. C. (2019). Faktor-Faktor Yang Mempengaruhi Kelancaran Produksi Asi. Jurnal 'Aisyiyah Medika, 4(1). https://doi.org/10.36729/jam.v4i1.230

Frieska. P, Windhu. P, R. . (2018). Maternal Parity and Onset of Lactation on Postpartum Mothers. 2(2), 212-220.

Kemenkes RI. (2018). Buletin Stunting. Kementerian Kesehatan RI, 301(5), 1163-1178.

Kementerian Kesehatan RI. (2019). Profil Kesehatan Indonesia Tahun 2019.

Kitano, N., Nomura, K., Kido, M., Murakami, K., Ohkubo, T., Ueno, M., \& Sugimoto, M. (2016). Combined effects of maternal age and parity on successful initiation of exclusive breastfeeding. Preventive Medicine Reports, 3, 121-126. https://doi.org/10.1016/j.pmedr.2015.12.0 10

Meedya, S., Fahy, K., \& Kable, A. (2010). Faktors that positively influence breastfeeding duration to 6 months: A literature review. Women and Birth, 23(4), 135-145. https://doi.org/10.1016/j.wombi.2010.02. 002

Pranajaya dkk. (2013). Determinan Produksi ASI pada Ibu Menyusui. Jurnal Keperawatan, IX(2), 227-237.

Rahmawati, A., \& Prayogi, B. (2017). Analisis Faktor yang Mempengaruhi Produksi Air Susu Ibu (ASI) Pada Ibu Menyusui yang Bekerja (Analysis of Faktors Affecting Breastmilk Production on Breastfeeding Working Mothers). Jurnal Ners Dan Kebidanan, 4(2), 134-140. https://media.neliti.com/media/publicatio ns/232701-analysis-of-faktors-affectingbreastmilk-a8fa2353.pdf

Sarwono Prawirohardjo. (2014). Ilmu Kebidanan (4th ed.). PT Bina Pustaka Sarwono Prawirohardjo.

Trio Linda F.E.R, S. R. . (2015). Hubungan Frekuensi Dan Lama Menyusu Dengan. Media Gizi Indonesia, 10(1), 38-43. 